\title{
MUSTAHERUKAN KUKANKEHITYS JA MARJANMUODOSTUS
}

\author{
J. E. HÅrdh ja Johanna WaLlden ${ }^{1}$ ) \\ Helsingin yliopiston Puutarhatieteen laitos, Viik, Pihlajamäki
}

Saapunut 16. 1. 1965

Mustaherukan, samoin kuin muiden viljeltyjen sekä luonnonvaraisten marjakasvien kukanaiheet kehittyvät kesän ja talvikauden aikana seuraavan kasvukauden kukintaa varten. Kukkien määrä, niiden kehitys sekä pölyttyminen riippuvat siitä, miten kukanaiheet edellisenä vuonna ovat muodostuneet. Kun kukinnan ja pölytyksen kulku määrää sadon suuruuden ja laadun, on kukan kehityksen samoin kuin kukinnan ja marjanmuodostuksen tunteminen tieteelliseltä ja käytännölliseltä kannalta merkityksellistä. Mustaherukan kukan- ja marjankehitys on jo aikaisemmin monissa maissa tutkittu, joten asia pääpiirteissään on tunnettua. Näihin kehitysilmiöihin vaikuttavat kuitenkin ratkaisevasti ilmastolliset ja maantieteelliset seikat, erityisesti lämpötila ja valoisuus, joten eri seuduilla ja leveysasteilla tapahtuu kehitys varsin eri aikaan ja eri tavoin, mikä on osoitettu mm. Rosaceaeheimon kasveista omenan, tuomen, mesimarjan ja suomuuraimen suhteen $(20,21)$. Lisäksi tiedetään, että mustaherukan kukankehitys, kukinta ja marjanmuodostus voivat tapahtua eri lajikkeilla toisistaan poikkeavin tavoin $(3,7,8,9,10 \mathrm{ym}$.). Kun 60. leveysastetta pohjoisempana olevilla alueilla, yhtä vähän kuin tärkeimmillä kotimaisilla mustaherukkalajikkeillammekaan ei näitä asioita ollut vielä selvitetty, ryhdyttiin Yliopiston puutarhatieteen laitoksella asiaa vuonna 1961 tarkemmin tutkimaan.

\section{Kukanaiheiden erilaistuminen}

Kasvukauden alussa alkavat mustaherukan lehtihangoissa olevat silmut kehittyä, ja noin kesäkuun puoliväliin - Keski-Euroopassa toukokuun puoliväliin (9) — saakka niiden kehitys on vastaavasta lehdestä riippuvainen. Jos lehti tänä aikana poistetaan, silmu joko surkastuu tai pysähtyy kehityksessään pitkäksi ajaksi. Sanotun ajankohdan jälkeen hankasilmu itsenäistyy, tulee lehdestä riippumattomaksi ja siinä alkavat muodostua uusien lehtien aiheet. Näin alkanut

1) Maat.- ja metsät. kand. Irma Voipio on suorittanut työhön liittyvät mikroskooppiset tutkimukset ja määritykset. Työtä varten on Valtion Maatalous-metsätieteellinen toimikunta myöntänyt kolmeksi vuodeksi apurahan. 
silmun vegetatiivinen vaihe päättyy vuorostaan silloin, kun kasvupiste, joka vegetatiivisessa silmussa on kartiomainen, alkaa leventyä ja kun sen pinnalle ilmaantuu pieniä rakkomaisia ulkonemia, alkuasteella olevia kukanaiheita. Tämä ajankohta, jolloin silmu siirtyy vegetatiivisesta generatiiviseen vaiheeseen, vaihtelee eri lajikkeilla eri vuosina $(3,9)$ ja liittyy kasvin muuhun kehitykseen. Niinpä LeNz (9) totesi useista lajikkeista, että pääversoissa, joissa päätesilmu muodostuu myöhemmin kuin lyhyissä sivuverhoissa, myös generatiivinen vaihe alkaa myöhemmin kuin sivuversoissa. Näin oli laita yhtä lukuun ottamatta kaikilla hänen tutkimillaan lajikkeilla. Sensijaan sellaisissa sivuversoissa, joissa oli jo kypsyviä marjoja, alkoi hänen havaintojensa mukaan kukanaiheiden erilaistuminen jopa kymmentä päivää aikaisemmin kuin sivuversoissa, joissa oli vain vihreitä marjanraakileita. Erilaistumisen ajankohta näyttää siis riippuvan versonkasvusta sekä versossa olevien marjojen kehitysasteesta.

Saman verson eri silmuissa alkaa kukanaiheiden erilaistuminen eri aikana. Sivuversoissa, joiden pituuskasvu on hidasta ja päättyy aikaisin, ovat erot eri silmujen kehityksessä vähäiset; sen sijaan pääversoissa ovat erot sitä suuremmat, kuta kauemmin verson kasvua jatkuu. Samassa silmussa ovat erot eri kukkien aiheiden kehitysasteessa (vrt. seur.) sitä suuremmat, kuta suurempi on kukkien lukumäärä kukinnossa. Täten kukinnon eri kukat ovat toisiinsa nähden eri asemassa, meriarvoisia», millä seikalla on ratkaiseva merkitys myöhemmin kukkien aukeamiselle ja raakileiden varisemiselle. RudLOFF ja LENz (13) ovat huomanneet, että silmun ensimmäiset kukanaiheet syntyvät pääkukinnon tyveen, minkä jälkeen muut kukanaiheet sekä lopuksi kaksi päätekukkaa kehittyvät. Vasta tämän jälkeen muodostuvat sivukukintojen kukanaiheet. Ensiksi muodostuneet kukanaiheet ovat silmuissa vahvimmat ja hidastavat muiden kukkien kehitystä. Kuta kauempana kukka on tertun tyvestä, sitä heikompi on sen kehitys ja sitä helpommin se tai siitä kehittyvä raakile varisee. Jos tyvikukkien aiheet taikka tyvikukat poistetaan, alkavat kauempana tertun syvestä olevat kukat kehittyä voimakkaasti, kuten NeumanN (11) sekä RUdLOFF ja Lenz (13) totesivat.

Mainittakoon, että raakileiden variseminen riippuu myös pölytystavasta, kuten myöhemmin (s. 72) osoitetaan.

Kukanaiheen ja kukan kehityksessä erotetaan Zellerin $(19,20)$ sekä LeNzin (9) mukaan seuraavat kymmenen vaihetta:

I kasvupisteen laajeneminen kartiomaiseksi

II rakkomaisia pullistumia kartion pinnalla, verhiön aiheet kehittyneet

III yksittäisten kukanaiheiden leviäminen lautasmaisiksi levyiksi, teriön erilaistuminen

IV heteiden aiheiden muodostuminen

$\mathrm{V}$ emiön aiheiden muodostuminen

VI emiön kehittyminen verhiön sisään, siitepölyemosolut kehittyneet heteissä

VII tertun ja kukkaperien pituuskasvu, siemenaiheen muodostuminen

VIII siitepölytetradit sekä emin luotit muodostuvat

IX kukinta ja raakileenmuodostus

$\mathrm{X}$ marjan kypsyminen ja värittyminen. 
Marjojen kypsyessä versoissa alkaa uusissa silmuissa samanaikaisesti kukanaiheiden erilaistuminen. Saksassa suoritettujen tutkimusten mukaan $(9,14)$ kukanaiheiden erilaistuminen alkaa siellä kesäkuun alussa; elokuun kuluessa saavuttavat siellä ensimmäiset kukanaiheet V:n asteen, millä silmut talvehtivat, ja syyskuun ja lokakuun kuluessa tulevat kehityksessään hitaimmatkin päätekukat sekä sivukukintojen kukanaiheet sanotulle kehitysasteelle. Keväällä maaliskuun alussa alkavat silmut edelleen kehittyä kukintaan saakka, joka siellä tapahtuu enimmäkseen huhtikuussa.

Etelä-Ruotsissa alkaa mustaherukan kukanaiheiden erilaistuminen FERNgvisTin (3) mukaan heinäkuun 15. päivän aikaan ja saavuttaa talvehtivan asteen lokakuun puolivälissä. Mustaherukka kukkii siellä huhtikuun lopusta toukokuun puoliväliin saakka.

Menetelmät. Vuosinä 1962-1964 otettiin Viikistä, Puutarhatieteen laitoksen koekentältä, vuonna 1960 istutetuista Brödtorp, Lepaan musta, Silvergieter (Silvergieters Zwarte) ja Wellington xxx-lajikkeista aina 14 päivän kuluttua kolme pääversoa, joista tutkittiin kymmenen peräkkäistä silmua verson kärjestä lukien, laskettiin kukkien lukumäärä sekä määritettiin kehitysaste kussakin silmussa. Täten käsiteltiin vuosittain kustakin lajikkeesta noin 450 silmua.

Lisäksi selvitettiin päivänpituuden vaikutusta erilaistumisen kulkuun keräämällä neljästä lajikkeesta versonäytteitä neljältä eri leveysasteelta Suomesta sekä valottamalla kolmea ryhmää (à 4 pensasta) Brödtorp-pensaita Viikissä siten, että päivänpituudet kasvukauden aikana eri ryhmissä olivat 18, 21 ja 24 tuntia. Muut kasvuolosuhteet sekä lannoitus olivat kaikilla ryhmillä samanlaiset. Myös näistä kasveista tutkittiin versonäytteet aina 14 päivän kuluttua edellä kuvatulla tavalla. Kuukauden keskilämmöt seuduilla, joista näytteet kerättiin, esitetään taulukossa 1.

Taulukko 1. Kuukauden keskilämmöt neljällä paikkakunnalla vuosina 1962-1964.

Table 1. Monthly mean temperatures on four test localities in 1962-1964.

\begin{tabular}{rrrrrr} 
& $\begin{array}{c}\text { Kuukausi } \\
\text { Month }\end{array}$ & Helsinki & Kuopio & Oulu & Rovaniemi \\
\hline \multirow{2}{*}{1962} & IV & 4.0 & 3.2 & 2.1 & 0.5 \\
& V & 8.6 & 8.1 & 6.9 & 5.1 \\
VI & 12.0 & 11.9 & 11.0 & 9.8 \\
& VII & 15.2 & 14.0 & 13.6 & 11.7 \\
& VIII & 13.5 & 11.8 & 11.8 & 10.3 \\
& IX & 10.4 & 8.8 & 8.0 & 6.5 \\
& X & 7.7 & 5.3 & 4.8 & 1.4 \\
& IV & 2.8 & 1.7 & 1.1 & 0.0 \\
& V & 12.5 & 12.4 & 11.3 & 10.5 \\
& VI & 15.0 & 13.0 & 11.8 & 10.5 \\
& VII & 16.7 & 16.1 & 14.6 & 13.2 \\
& VIII & 17.1 & 15.6 & 14.5 & 13.0 \\
& IX & 13.6 & 12.2 & 11.2 & 9.3 \\
& X & 7.2 & 4.8 & 3.6 & 1.7 \\
& XI & 2.6 & 0.4 & -0.2 & -2.5 \\
& XII & -2.6 & -7.6 & -6.7 & -9.3 \\
& I & -1.9 & -5.3 & -3.6 & -6.4 \\
& II & -7.8 & -11.9 & -10.7 & -12.7
\end{tabular}




\section{Kukanaiheiden erilaistumisaika}

Tutkittujen mustaherukkalajikkeiden silmuissa oli 4-11 kukanaihetta kussakin kukinnossa. Aikaisimmin kehittyneiden kukanaiheiden mukaan määritettiin silmun keskimääräinen kehitysvaihe. Siten todettiin, että ensimmäisenä alkoi Viikissä silmujen generatiivinen vaihe Lepaan musta -lajikkeella vuosina 1962 ja 1963 heinäkuun 10. päivän aikaan ja Brödtorpilla elokuun alussa. Myös kukanaiheiden kehitysnopeudessa oli mainittujen lajikkeiden kesken selvä ero, kuten taulukosta 2 ilmenee. Ulkomaisista lajikkeista Wellington xxx:lla alkoi kukanaiheiden erilaistuminen elokuun 14. päivänä, eli noin viikkoa myöhemmin kuin Brödtorpilla, ja Silvergieterillä elokuun 20. p:nä. Eri vuosina ei samalla lajikkeella voitu todeta eroja kehityksen alkuun eikä kehitysnopeuteen nähden. Taulukossa on kehitysasteet merkitty arabialaisilla numeroilla roomalaisten sijasta.

Taulukko 2. Kukanaiheiden keskimääräinen kehitysaste neljällä mustaherukkalajikkeella Viikissä

$$
\text { v. } 1962-1964
$$

Table 2. Mean differentiation stages of flower primordia on four black currant varieties in Viik, close to Helsinki, in 1962-1964.

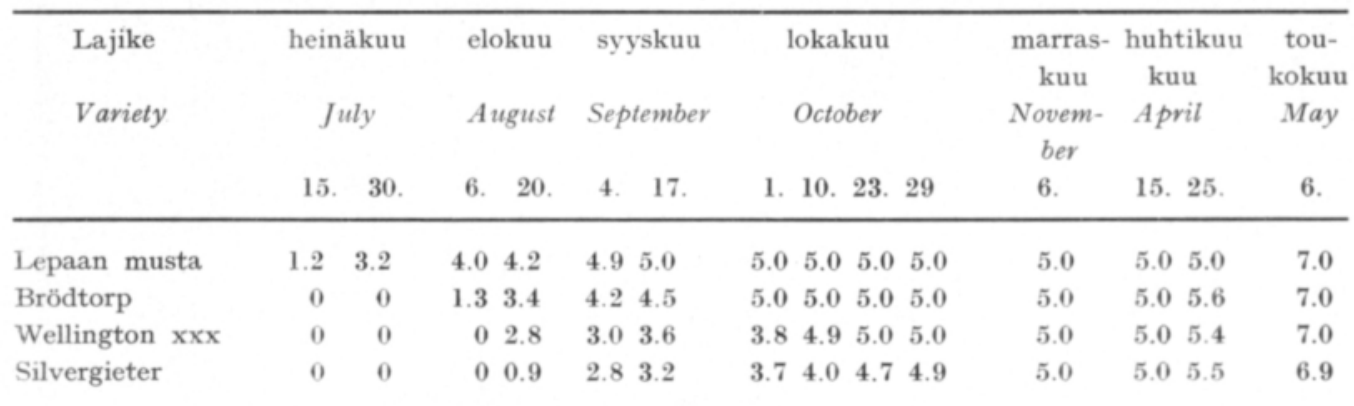

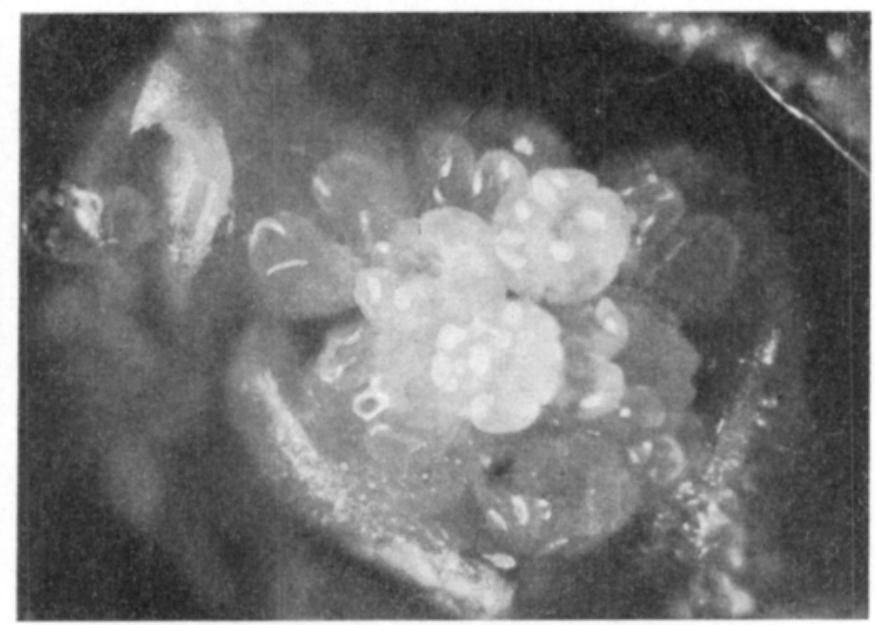

Kuva 1. Avattu mustaherukan silmu, jossa kuusi vihreätä, kolme väritöntä kukanaihetta. Lajike Brödtorp. Viik 15. 1. 1965.

Fig. 1. Bud of black currant opened. Six green, three white primordia showing. Variety Brödtorp. Viik 15. 1. 1965 . 
Silmussa olevan kukinnon (tertun) aiheessa on sekä vihreitä, kolmannen kehitysasteen sivuuttaneita, että värittömiä kukanaiheita (kuva 1) jotka eivät vielä ole saavuttaneet tätä astetta. Vihreiden kukanaiheiden prosenttinen osuus silmun kukanaiheiden koko määrästä kuvaa taulukossa 3 kaikkien kukkien kehitystä eri silmuissa.

Taulukossa 2 esitetään kukanaiheiden kehitysasteet 30 silmun pisimmälle kehittyneiden kukanaiheiden keskiarvoina. Huomataan, että Lepaan mustan ensimmäiset kukanaiheet saavuttivat Viikissä viidennen asteen syyskuun puolivälissä, ja taulukon 3 mukaan sen viimeisetkin kukanaiheet olivat tällä asteella marraskuun alkupäivinä. Silmujen kehitys pysähtyy talven ajaksi viidennen asteen saavutettuaan, mikä on myös muissa maissa todettu $(3,9,14)$. Tälle kehitysasteelle on ominaista, että kaikki kukan osat ovat silloin morfologisesti kehittyneet ja selvästi havaittavissa, mutta histologisesti katsoen ovat sukusolujen emosolut silloin vielä muodostumatta, mikä tapahtuu vasta VI ja VII asteella keväällä.

Taulukko 3. Vihreiden kukanaiheiden (kehitysasteet $3-5$ ) määrä $\%$ :na aiheiden koko määrästä 10 peräkkäisessä silmussa verson kärjestä lukien v. 1963-1964.

Table 3. Percentages of green flower primordia (stages 3-5) of all primordia in ten successive buds from the shoot tip, in 1963-1964.

\begin{tabular}{|c|c|c|c|c|c|c|c|c|c|c|c|c|c|c|c|c|c|c|c|c|}
\hline Pvm & & & & naa & $\mathrm{m}$ & sta & & & & & & & & Brö & tor & & & & & \\
\hline Date & 1 & 2 & 3 & 4 & 5 & 6 & 7 & 8 & 9 & 10 & 1 & 2 & 3 & 4 & 5 & 6 & 7 & 8 & 9 & 10 \\
\hline
\end{tabular}

\begin{tabular}{|c|c|c|c|c|c|c|c|c|c|c|c|c|c|c|c|c|c|c|c|c|c|}
\hline 63 & 6. 8. & 0 & 15 & 50 & 40 & 0 & 0 & 40 & 0 & 50 & 0 & 0 & 0 & 0 & 0 & 0 & 0 & 0 & 0 & 0 & 0 \\
\hline & 19. 8. & 0 & 57 & 57 & 70 & 75 & 85 & 85 & 85 & 85 & 85 & 0 & 0 & 20 & 11 & 47 & 32 & 32 & 50 & 50 & - \\
\hline & 10.10 . & 0 & 56 & 71 & 68 & 77 & 75 & 68 & 74 & 63 & 62 & 0 & 48 & 48 & 62 & 60 & 57 & 48 & 58 & 59 & 54 \\
\hline & 23.10 . & 0 & 95 & 95 & 95 & 100 & 95 & 95 & 96 & 87 & 85 & 0 & 75 & 76 & 77 & 85 & 78 & 79 & 86 & 84 & 88 \\
\hline & 6.11. & 0 & 100 & 100 & 100 & 100 & 96 & 100 & 100 & 100 & 100 & 0 & 91 & 95 & 87 & 91 & 96 & 96 & 96 & 100 & 100 \\
\hline & 20.11 . & & & & & & & & & & & 0 & 94 & 90 & 91 & 89 & 95 & 86 & 95 & 85 & 95 \\
\hline & 4.12. & & & & & & & & & & & 0 & 100 & 91 & 92 & 100 & 100 & 96 & 96 & 100 & 96 \\
\hline & 18.12 . & & & & & & & & & & & 0 & 89 & 88 & 95 & 96 & 96 & 92 & 92 & 96 & 100 \\
\hline 964 & 15. 1. & & & & & & & & & & & 0 & 91 & 95 & 96 & 96 & 96 & 96 & 100 & 100 & 100 \\
\hline & 29. 1. & & & & & & & & & & & 0 & 100 & 100 & 100 & 100 & 100 & 100 & 100 & 100 & 100 \\
\hline
\end{tabular}

Wellington $\mathbf{x x x}$

$\begin{array}{rrrrrrrrrrrrrrrrrrrrrr}196317.9 . & 0 & 14 & 20 & 25 & 33 & 30 & - & 18 & 25 & 25 & 0 & 0 & 0 & 0 & 22 & 22 & 30 & - & 30 & 50 \\ 10.10 . & 0 & 19 & 20 & 4 & 21 & 21 & 14 & 26 & 31 & 28 & 0 & 9 & 5 & 0 & 5 & 25 & 18 & 24 & 25 & 31 \\ 23.10 . & 54 & 59 & 71 & 68 & 68 & 64 & 58 & 76 & 75 & 72 & 53 & 48 & 52 & 44 & 50 & 57 & 53 & 54 & 46 & 54 \\ 6.11 . & 0 & 50 & 48 & 63 & 57 & 64 & 67 & 63 & 63 & 67 & 44 & 59 & 57 & 55 & 57 & 67 & 65 & 62 & 61 & 70 \\ 20.11 . & 38 & 62 & 71 & 72 & 68 & 63 & 74 & 65 & 77 & 65 & 75 & 47 & 74 & 73 & 78 & 75 & 76 & 77 & 67 & 75 \\ \text { 4.12. } & 43 & 39 & 61 & 73 & 65 & 75 & 74 & 77 & 73 & 72 & 0 & 40 & 52 & 77 & 71 & 68 & 63 & 69 & 70 & 78 \\ 18.12 . & 0 & 71 & 86 & 83 & 86 & 88 & 87 & 87 & 88 & 77 & 0 & 68 & 81 & 91 & 96 & 88 & 81 & 79 & 95 & 78 \\ 1964 \text { 15. 1. } & 0 & 75 & 83 & 86 & 78 & 96 & 79 & 82 & 88 & 88 & 0 & 87 & 100 & 85 & 88 & 88 & 92 & 84 & 81 & 78 \\ 29 . & 1 . & 57 & 71 & 75 & 91 & 83 & 86 & 79 & 77 & 80 & 82 & 75 & 76 & 71 & 87 & 87 & 83 & 88 & 92 & 92 & 88 \\ 12 . & 2 . & 0 & 77 & 91 & 88 & 96 & 88 & 96 & 84 & 92 & 96 & 100 & 87 & 100 & 83 & 100 & 100 & 91 & 100 & 85 & 92 \\ 26 . & 2 . & 71 & 80 & 85 & 85 & 95 & 95 & 91 & 100 & 96 & 100 & 100 & 89 & 90 & 95 & 95 & 95 & 95 & 90 & 90 & 88 \\ 12.3 . & 0 & 90 & 90 & 96 & 95 & 96 & 91 & 91 & 100 & 88 & 0 & 82 & 91 & 95 & 100 & 96 & 92 & 100 & 100 & 100 \\ 26.3 . & 85 & 74 & 78 & 96 & 100 & 91 & 96 & 79 & 89 & 87 & 96 & 100 & 100 & 96 & 100 & 100 & 100 & 100 & 100 & 100 \\ 9.4 & 86 & 95 & 86 & 88 & 96 & 100 & 96 & 92 & 100 & 91 & 100 & 100 & 100 & 96 & 100 & 100 & 100 & 100 & 100 & 100\end{array}$


Brödtorpilla alkaa Viikissä erilaistuminen elokuun 6. päivän aikaan, ja ensimmäiset kukanaiheet saavuttavat $\mathrm{V}$ asteen lokakuun alussa. Viimeiseksi kehittyneet Brödtorpin kukanaiheet ovat tällä asteella vasta tammikuun lopussa.

Ulkomaisilla Wellington xxx ja Silvergieter -lajikkeilla alkaa erilaistuminen myöhemmin kuin kotimaisilla lajikkeilla, elokuun puolivälin jälkeen, ja ensimmäiset kukanaiheet saavuttavat V asteen lokakuun lopussa, Wellingtonilla noin viikkoa ennen Silvergieteriä. Huomattava seikka on kukanaiheiden jatkuva kehittyminen talven aikana huolimatta alhaisista lämpötiloista, mikä ilmenee taulukosta 3. Viimeiset kukanaiheet saavuttavat $\mathrm{V}$ asteen vasta huhtikuussa, Wellingtonilla kahta viikkoa myöhemmin kuin Silvergieterillä. Tällöin alkavat lämpötilan kohotessa kuitenkin jo ensimmäiset kukanaiheet jatkaa kehitystään VI asteelle ja edelleen kukintaa kohden. Mustaherukan silmujen kehittymistä talven aikana alhaisissa lämpötiloissa V kehitysasteeseen saakka on aikaisemmin todettu vain arktisilla seuduilla Murmanskissa ja Vladivostokissa $(16,17)$. Eteläisemmillä seuduilla taas hedelmäpuiden sekä herukkalajien silmut saavuttavat $\mathrm{V}$ asteen jo ennen talven tuloa, kuten aikaisemmin mainittiin.

Taulukosta 3 havaitaan, että verson silmut ovat kehityksessään ehtineet sitä pitemmälle kuta kauempana ne ovat verson kärjestä ja että päätesilmu kotimaisilla lajikkeilla useimmiten pysyy vegetatiivisella asteella. Erot eri silmujen kesken ovat sitä suuremmat, kuta pitemmät ovat silmujen välimatkat versossa (9).

Taulukko 4. Kukanaiheiden kehitysvaiheet sekä erilaistumisen alkamisaika Viikissä $\left(60^{\circ} 10^{\prime}\right)$, Maaningalla $\left(63^{\circ} 9^{\prime}\right)$, Lumijoella $\left(64^{\circ} 50^{\prime}\right)$ ja Tervolassa $\left(66^{\circ} 5^{\prime}\right)$ vuosina $1963-1964$.

Table 4. Mean stages of primordia and dates of start of differentiation in Viik $\left(60^{\circ} 10^{\prime}\right)$, Maaninka $\left(63^{\circ} 9^{\prime}\right)$, Lumijoki $\left(64^{\circ} 50^{\prime}\right)$ and in Tervola $\left(66^{\circ} 5^{\prime}\right)$ in $1963-1964$.

\begin{tabular}{|c|c|c|c|c|}
\hline $\begin{array}{l}\text { Lajike } \\
\text { Variety }\end{array}$ & 10.10 & 28.11 . & 20.1 . & $\begin{array}{l}\text { Erilaistuminen } \\
\text { alkoi (pvm) } \\
\text { Differentiation } \\
\text { started on }\end{array}$ \\
\hline \multicolumn{5}{|l|}{ Lepaan musta } \\
\hline - Viik & 5.0 & 5.0 & 5.0 & 10.7 . \\
\hline - Maaninka & 5.0 & 5.0 & 5.0 & - \\
\hline - Lumijoki & 5.0 & 5.0 & 5.0 & - \\
\hline - Tervola & 4.7 & 5.0 & 5.0 & 10.8 . \\
\hline \multicolumn{5}{|l|}{ Brödtorp } \\
\hline - Viik & 5.0 & 5.0 & 5.0 & 1.8. \\
\hline - Maaninka & 5.0 & 5.0 & 5.0 & - \\
\hline - Lumijoki & 3.9 & 4.8 & 5.0 & 5.8. \\
\hline - Tervola & 3.9 & 3.3 & 4.3 & 5.8. \\
\hline \multicolumn{5}{|l|}{ Wellington $\mathbf{x x x}$} \\
\hline - Viik & 4.9 & 5.0 & 5.0 & 10.8 \\
\hline - Maaninka & 4.0 & 4.9 & 5.0 & 20.8 . \\
\hline - Lumijoki & 3.4 & 4.7 & 4.7 & 5.9. \\
\hline - Tervola & 2.9 & 1.4 & 3.6 & 20.9 . \\
\hline \multicolumn{5}{|l|}{ Laxtons Tinker } \\
\hline - Viik & 4.0 & 5.0 & 5.0 & 20.8 . \\
\hline - Maaninka & 4.1 & 5.0 & 5.0 & 30.8 . \\
\hline - Lumijoki & 2.4 & 3.8 & 3.7 & 1.10. \\
\hline - Tervola & 2.4 & 3.1 & 3.9 & 1.10. \\
\hline
\end{tabular}




\section{Kukanaiheiden erilaistuminen ja päivänpituus}

BÜNNING ja KoNDER (2) ovat osoittaneet, että sellaiset päivänpituusolosuhteet, jotka hidastavat lehtien kasvua, edistävät kukanaiheiden kehittymistä. ALLEWELDT (1) puolestaan on viiniköynnöksestä todennut, että fotoperiodinen vaikutus kukanaiheisiin tapahtuu lähimmän lehden kautta. Siten lehden poisto tai varjostaminen aiheuttaa muutoksia vain vastaavan hankasilmun kehityksessä.

Neljältä eri leveysasteelta, Viikistä $\left(60^{\circ} 10^{\prime}\right)$, Maaningalta $\left(63^{\circ} 9^{\prime}\right)$, Lumijoelta $\left(64^{\circ} 50^{\prime}\right)$ ja Tervolasta $\left(66^{\circ} 5^{\prime}\right)$, kolmena ajankohtana kerätyistä versonäytteistä tehtyjen määritysten tulokset esitetään taulukossa 4. Kustakin versonäytteestä ja lajikkeesta tutkittiin kerrallaan 30 silmua.

Huomataan, että Lepaan mustan kukanaiheet saavuttavat V asteen PohjoisSuomessa, Tervolassa, marraskuun alkuun mennessä. Sen sijaan Brödtorpin silmujen kehitys jatkuu Lumijoella marras- ja joulukuulla, Tervolassa vielä tammikuun aikana. Wellingtonin sekä Laxtons Tinkerin kukanaiheet ovat vielä tammikuussa keskimäärin aikaisemmalla kuin IV asteella, mikä merkitsee, että kukanaiheiden kehitys jatkuu edelleen talvikuukausina. Paleltuneita tai muuten tuhoutuneita kukanaiheita tavattiin vain Lepaan musta -lajikkeesta, runsaimmin Maaningalta ja jonkin verran Lumijoelta saaduista näytteistä. Näin ulkomaisten Wellington ja Laxtons Tinker -lajikkeiden kukanaiheet ovat tutkimusvuonna talvehtineet hyvin ja jatkaneet kehitystään Pohjois-Suomessa talven aikana.

Taulukosta 4 todetaan myös, että erilaistuminen kaikilla lajikkeilla alkoi maan etelä- ja keskiosissa aikaisemmin kuin pohjoisempana. Kun heinä- ja elokuun lämpötilat poikkeavat toisistaan vain vähän eri osissa maata (taulukko 1), eivät näin suuret kehityksen alkamisen erot olleet selitettävissä vain lämpötilaerojen perusteella, vaan oletettavasti eroihin vaikutti pääosalta päivänpituus (taulukko 5).

Taulukko 5. Päivänpituus neljällä paikkakunnalla kasvukauden lopulla

Table 5. Day length (time from sunrise to sunset) on four localities in the end of growing season.



Taulukossa mainitun pituisen päivän lisäksi on kasveille tehollista valoa aamu- ja iltaruskon aikana, mitä kuitenkin on vaikea täsmällisesti määrittää. Taulukoista 3 ja 4 huomataan, että vaikka kotimaisten lajikkeiden Lepaan mustan ja Brödtorpin k u k in t a alkoi ja päättyi v. 1963 vain 4 päivää aikaisemmin kuin Wellingtonin ja Silvergieterin (taulukko 7), alkoi kukanaiheiden e ril a is t u m in e n kotimaisilla lajikkeilla Viikissä 20-30 päivää aikaisemmin kuin ulkomaisilla 
lajikkeilla. Lumijoella, lähellä Oulua, erot olivat $30-55$ päivää ja Tervolassa, lähellä Rovaniemeä, $45-55$ päivää. Mainitun pituisena aikana päivä lyhenee Lumijoella jopa 7 tuntia ja Tervolassa 7 tuntia 40 minuuttia ja on kotimaisten lajikkeiden erilaistumisen alkaessa noin 17 tuntia ja ulkomaisten lajikkeiden erilaistumisen alkaessa 12-13 tuntia. Viikissä olivat päivänpituudet vastaavana ajankohtana 16-17 tuntia ja 13-14 tuntia. Näyttää siis ilmeiseltä, että mustaherukan kukanaiheiden erilaistuminen on sitä hitaampaa, kuta pitempi päivä on, ja että erilaistuminen alkaa vasta päivänpituuden lyhetessä noin 13 tuntiin.

Päivänpituuden vaikutuksen edelleen toteamiseksi tehtiin Viikissä vuosina 1962 ja 1963 kokeita, joissa Brödtorp-lajikkeen pensaita kasvatettiin 18, 21 ja 24 tunnin pituisen päivän olosuhteissa. Taulukosta 6 huomataan, että 18 tunnin pitui-

Taulukko 6. Brödtorp-lajikkeen kukanaiheiden kehitysasteet päivänpituuden ollessa 18, 21 ja 24 tuntia Viikissä.

Table 6. Stages of primordia of black currant, variety Brödtorp, in day lengths of 18, 21 and 24 hours, in Viik.

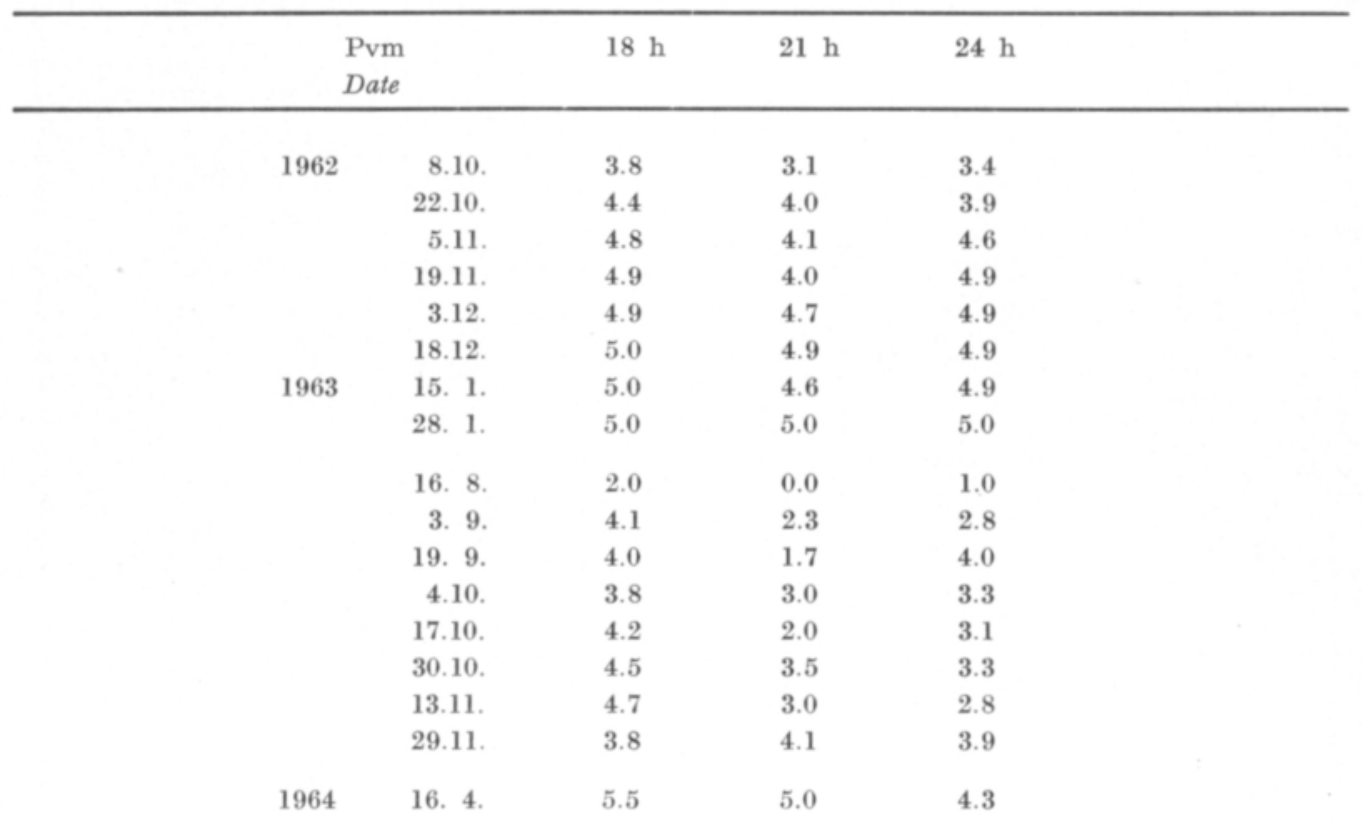

sen päivä nolosuhteissa olivat kukanaiheet $\mathrm{V}$ asteella vasta joulukuun puolivälissä, kun ne luontaisen päivänpituuden (taulukko 5) vallitessa edellisten vieressä kasvaneissa pensaissa olivat samalla asteella jo syyskuun lopussa (taulukko 2).

Kokeet vahvistavat sitä jo edellä mainittua toteamusta, että mustaherukan kukanaiheiden kehitystä hidastaa pitkä päivä ja että tämä kehitys on kvantitatiivisesti lyhyenpäivän reaktio. Edelleen ovat kotimaiset lajikkeet Lepaan musta ja Brödtorp ilmeisesti paremmin sopeutuneet pitkänpäivän olosuhteisiin kuin keskieurooppalaiset Wellington $\mathrm{xxx}$ ja Laxtons Tinker, kuten jo aikaisemminkin on todettu (5). 


\section{Kukinta}

Mustaherukan kukinnossa avautuvat ensimmäisinä kukat, jotka erilaistuessaan olivat silmussa muita pitemmälle kehittyneitä. Tertun tyvikukka avautuu ensimmäisenä ja sitä seuraavat kukat sijaintijärjestyksessa (13). Ero tyvi- ja kärkikukkien avautumisessa ja kukinta-ajassa riippuu kukinnan alkamisajan säästä ja lämpötilasta sekä tertun kukkien lukumäärästä. Mitä aikaisemmin kukinta alkaa ja mitä enemmän tertussa on kukkia, sitä kauemmin kukinta kestää. Siitä syystä on päätertun kukinta-aika yleensä pitempi kuin sivuterttujen. Etelä-Ruotsissa totesi FERNQvist (3) tertun viimeisten kukkien aukeavan, lajikkeesta riippuen, 6-9 päivää myöhemmin kuin ensimmäisten. Kukkia tertussa oli tällöin Brödtorpilla eri vuosina keskimäärin 7.4, Silvergieterillä 9.6, ja kaikilla 13 tutkitulla lajikkeella keskimäärin 8.0 .

Taulukko 7. Mustaherukkalajikkeiden kukinta-ajat Viikissä ja Maaningalla vuosina 1962 ja $1963^{1}$ ).

Table 7. Flowering dates of black currant varieties in Viik and Maaninka in 1962-1963.

\begin{tabular}{|c|c|c|c|c|c|c|}
\hline \multirow[t]{2}{*}{$\begin{array}{l}\text { Lajike } \\
\text { Variety }\end{array}$} & & \multicolumn{2}{|c|}{$\begin{array}{l}\text { Kukinta alkoi } \\
\text { Flowering started }\end{array}$} & \multicolumn{2}{|c|}{$\begin{array}{c}\text { Täysi kukinta } \\
\text { Full bloom }\end{array}$} & \multirow{2}{*}{$\begin{array}{l}\text { Kukinta päättyi } \\
\text { End of flowering } \\
\text { Viik }\end{array}$} \\
\hline & & Viik & Maaninka & Viik & Maaninka & \\
\hline \multirow[t]{2}{*}{ Lepaan musta } & 1962 & 19.5. & & 28.5 & & 16.6 . \\
\hline & 1963 & 17.5 & 22.5 & 20.5 & 26.5 & 31.5. \\
\hline \multirow[t]{2}{*}{ Brödtorp } & 1962 & 19.5 & & 28.5 & & 14.6. \\
\hline & 1963 & 17.5 & 22.5 & 22.5 & 26.5 . & 31.5 . \\
\hline \multirow[t]{2}{*}{ Wellington $\mathbf{x x x}$} & 1962 & 25.5 & & 9.6 & & 28.6 . \\
\hline & 1963 & 21.5 & 24.5 & 27.5 & 27.5 & 3.6. \\
\hline \multirow[t]{2}{*}{ Silvergieter } & 1962 & 25.5 & & 6.6. & & 26.6 . \\
\hline & 1963 & 21.5. & 24.5 & 27.5 & 27.5 & 3.6. \\
\hline \multirow[t]{2}{*}{ Laxtons Tinker } & 1962 & 28.5 & & 9.6 . & & 27.6 . \\
\hline & 1963 & 22.5 & 25.5 & 27.5 . & 28.5 & 3.6 . \\
\hline
\end{tabular}

1)Tiedot Maaningalla tehdyistä kukintahavainnoista on maisteri Annikki Ryynänen hyväntahtoisesti luovuttanut tässä käytettäväksi.

Taulukosta 7 nähdään, että kaikilla lajikkeilla kukinta kesti Viikissä kauemmin ja oli myöhäisempää v. 1962 kuin v. 1963. Tähän oli ilmeisesti syynä se, että touko- ja kesäkuun lämpötila v. 1962 (keskilämmöt 8.6 ja 12.0) oli alhaisempi kuin vastaavana aikana v. 1963 (keskilämmöt 12.5 ja 15.0, taulukko 1). Maaningalla alkoi ulkomaisten lajikkeiden kukinta v. 1963 3-4 päivää myöhemmin kuin samojen lajikkeiden kukinta Viikissä, kotimaisilla lajikkeilla Lepaan mustalla ja Brödtorpilla oli eroa 5 päivää.

\section{Pölytyssuhteet}

Kukkien pölyttymisestä seuraa, että siemenaiheet alkavat kehittyä ja marjat muodostua. Siemenaiheita on emiössä eri lajikkeilla todettu $47-130 \mathrm{kpl}$, joista kuitenkin vain osa, esim. $26.2 \%(10), 15 \%(15)$ tai $55 \%$ (3), kehittyy siemeniksi. Kun siemenaiheissa muodostuu kasvuaineita, pääasiassa auksiineja $(6,8,11)$, jotka aiheuttavat marjan kasvun sekä estävät irtaantumissolukon muodostumisen 
marjankantaan, riippuu marjojen koko sekä varisemisprosentti hedelmöittyneiden siemenaiheiden lukumäärästä. Näin pölytyksen onnistumisella ja pölytyssuhteiden tuntemisella on satoisuuden kannalta tärkeä käytännöllinen merkitys.

Pölytyssuhteiden mukaan ovat mustaherukkalajikkeet 1 . täysin itsefertiilejä, 2. osittain itsefertiilejä tai 3. osittain itsesteriilejä. Täysin itsesteriilejä mustaherukkalajikkeita tunnetaan vain kaksi, kanadalaiset Coronet ja Crusader $(8,12)$. Vain ensimmäisen ryhmän lajikkeita voidaan menestyksellisesti viljellä monokulttuurina, muihin ryhmiin kuuluvien lajikkeiden viljelyn onnistuminen taas riippuu vieraiden lajikkeiden siitepölyn saannista. FERNQvisTin (3) kokeissa antoivat kaikki tutkitut lajikkeet paremman marjasadon ristipölytyksen kuin itsepölytyksen jälkeen, myös yllä olevaan ensimmäiseen ryhmään kuuluvat lajikkeet Goliat ja Silvergieter. Brödtorp-lajikkeelle kehittyi tällöin marjoja vapaan pölytyksen seurauksena $69 \%$ :sta kukkia, kun niitä itsepölytyksen tapahduttua muodostui vain $45 \%$ :sta. Tämän perusteella näyttäisi Brödtorp kuuluvan ylläolevassa jaoittelussa toiseen ryhmään: se pölyttyy melko hyvin omalla siitepölyllään, mutta ristipölytys parantaa satoisuutta. Maassamme ei aikaisemmin ole tutkittu kotimaisten mustaherukkalajikkeiden fertiilisyyttä, mistä syystä asiaa selvitettiin Puutarhatieteen laitoksella vuosina 1963 ja 1964 .

Menetelmät. Vuonna 1963 tutkittiin Brödtorp ja Lepaan musta -lajikkeiden pölytyssuhteita suorittamalla pölytykset neljällä tavalla: 1. itsepölytys saman kukan siitepölyllä, 2. itsepölytys saman lajikkeen toisten kukkien siitepölyllä, 3. ristipölytys toisella kotimaisella lajikkeella ja 4. ristipölytys Wellington xxx:n siitepölyllä. Vuonna 1964 uusittiin kokeet samalla tavalla Puutarhantutkimuslaitoksen kasvimateriaalilla Piikkiössä. Ennen pölytystä emaskuloitiin aukeamaisillaan olevat nuput, niiden pölyttäminen suoritettiin siveltimellä, muut kukat poistettiin tertuista ja oksat pantiin kankaisiin eristyspusseihin. Kullakin tavalla käsiteltiin kolmessa oksassa olevat tertut. Pölytys tapahtui 20.—21. 5. 1963 ja 27.-28. 5. 1964. Eristyspussit poistettiin 20 päivän kuluttua pölytyksestä, jotta normaali marjankehitys ei häiriintyisi, mutta pantiin paikoilleen tästä 21 päivän kuluttua marjojen suojaamiseksi linnuilta sekä varisemiselta. Marjat poistettiin niiden kypsyttyä, ne punnittiin ja siemenet laskettiin. Viimeiset marjat koekasveista korjattiin $\mathbf{v}$. 1963 6.8. ja v. 1964 17. 8.

Taulukko 8. Brödtorp-lajikkeen pölytyskokeen tulokset vv. 1963 ja 1964.

Table 8. Results of pollination tests with Brödtorp-variety in 1963-1964.

Käsittelyt: 1. kukansisäinen pölytys - pollination within flower

Treatments: 2. lajikkeensisäinen pölytys - pollination within variety

3. ristipölytys Lepaan mustalla - cross-pollination with Lepaan musta

4. ristipölytys Wellington xxx:lla - cross-pollination with Wellington $x x x$.

\begin{tabular}{|c|c|c|c|c|c|c|c|c|c|c|}
\hline \multirow[t]{2}{*}{$\begin{array}{l}\text { Käsittely } \\
\text { Treatment }\end{array}$} & \multicolumn{2}{|c|}{$\begin{array}{c}\text { Kukkia pölytetty } \\
\text { kpl } \\
\text { Number of flowers } \\
\text { pollinated }\end{array}$} & \multicolumn{2}{|c|}{$\begin{array}{l}\text { Raakileita \% } \\
\text { Unripe ber- } \\
\text { ries \% }\end{array}$} & \multicolumn{2}{|c|}{$\begin{array}{l}\text { Marjoja \% } \\
\text { Ripe ber- } \\
\text { ries \% }\end{array}$} & \multicolumn{2}{|c|}{$\begin{array}{l}\text { Marjan keski- } \\
\text { paino g } \\
\text { Mean weight } \\
\text { of berry g. }\end{array}$} & \multicolumn{2}{|c|}{$\begin{array}{l}\text { Siementen lu- } \\
\text { kumäärä } \\
\text { Number of } \\
\text { seeds }\end{array}$} \\
\hline & 1963 & 1964 & 1963 & 1964 & 1963 & 1964 & 1963 & 1964 & 1963 & 1964 \\
\hline 1 & 18 & 48 & 88 & 92 & 88 & 92 & 0.60 & 1.07 & 37.1 & 40.7 \\
\hline 2 & 46 & 63 & 86 & 73 & 82 & 58 & 0.56 & 0.77 & 30.4 & 26.0 \\
\hline 3 & 61 & 58 & 64 & 77 & 64 & 59 & 0.44 & 1.12 & 27.9 & 34.7 \\
\hline 4 & 18 & 73 & 84 & 67 & 80 & 66 & 0.51 & 1.23 & 41.0 & 45.3 \\
\hline
\end{tabular}


Taulukko 9. Lepaan musta-lajikkeen pölytyskokeen tulokset vv. 1963 ja 1964.

Table 9. Results of pollination tests with Lepaan musta-variety in 1963-1964.

Käsittelyt: 1. kukansisäinen pölytys - pollination within flower

Treatments: 2. lajikkeensisäinen pölytys - pollination within variety

3. ristipölytys Brödtorpilla - cross-pollination with Brödtorp

4. ristipölytys Wellington xxx:lla - cross-pollination with Wellington xxx.

\begin{tabular}{|c|c|c|c|c|c|c|c|c|c|c|}
\hline \multirow[t]{2}{*}{$\begin{array}{l}\text { Käsittely } \\
\text { Treatment }\end{array}$} & \multicolumn{2}{|c|}{$\begin{array}{c}\text { Kukkia pölytetty } \\
\text { kpl } \\
\text { Number of flowers } \\
\text { pollinated }\end{array}$} & \multicolumn{2}{|c|}{$\begin{array}{l}\text { Raakileita \% } \\
\text { Unripe ber- } \\
\text { ries } \%\end{array}$} & \multicolumn{2}{|c|}{$\begin{array}{l}\text { Marjoja \% } \\
\text { Ripe ber- } \\
\text { ries } \%\end{array}$} & \multicolumn{2}{|c|}{$\begin{array}{l}\text { Marjan keski- } \\
\text { paino } \mathrm{g} \\
\text { Mean weight } \\
\text { of berry } \mathrm{g} .\end{array}$} & \multicolumn{2}{|c|}{$\begin{array}{l}\text { Siementen lu- } \\
\text { kumäärä } \\
\text { Number of seeds }\end{array}$} \\
\hline & 1963 & 1964 & 1963 & 1964 & 1963 & 1964 & 1963 & 1964 & 1963 & 1964 \\
\hline 1 & 21 & 52 & 87 & 98 & 84 & 94 & 0.48 & 1.59 & 29.8 & 74.3 \\
\hline 2 & 36 & 36 & 76 & 86 & 56 & 82 & 0.37 & 1.33 & 30.6 & 40.0 \\
\hline 3 & 37 & 41 & 67 & 82 & 67 & 67 & 0.43 & 1.01 & 30.9 & 43.0 \\
\hline 4 & 37 & 60 & 82 & 91 & 80 & 89 & 0.49 & 0.80 & 44.7 & 40.0 \\
\hline
\end{tabular}

Taulukoissa 8 (Brödtorp) ja 9 (Lepaan musta) ilmaistaan erikseen raakileiden määrä ja kypsien marjojen määrä prosentteina kukkien lukumäärästä. Näiden prosenttilukujen erotus osoittaa varisseiden raakileiden määrän, joka esitetään seuraavassa asetelmassa.

\begin{tabular}{ccccc} 
Käsittely & \multicolumn{2}{c}{ Brödtorp } & \multicolumn{2}{c}{ Lepaan musta } \\
& 1963 & 1964 & 1963 & 1964 \\
1 & 0 & 0 & 3 & 4 \\
2 & 4 & 15 & 20 & 4 \\
3 & 0 & 18 & 0 & 0 \\
4 & 4 & 1 & 2 & 2
\end{tabular}

Edellä esitetyistä taulukoista sekä asetelmasta havaitaan, että suurin määrä marjoja kumpanakin vuonna sekä Lepaan mustasta että Brödtorpista on saatu kukansisäisellä itsepölytyksellä. Tällöin oli myös raakileiden variseminen keskimäärin vähäisintä. Suurimmat Lepaan mustan marjanpainot antoi kukansisäinen itsepölytys, kun taas pölytys Brödtorpilla tuotti pienimmät marjat. Lajikkeensisäinen pölytys näytti antavan pienimmät marjat Brödtorpilla. Kummallakin oli Wellington xxx parempi pölyttäjä kuin toinen kotimainen lajike.

Taulukko 10. Varisseiden marjojen siemenmäärät ja marjanpainot. Käsittelyt kuten taul. 8 ja 9.

Table 10. Seed numbers and berry weights of dropped berries. Treatments see tables 8 and 9 .

\begin{tabular}{lclcc} 
& \multicolumn{2}{c}{ Brödtorp } & \multicolumn{2}{c}{ Lepaan musta } \\
Käsittely & Siemeniä kpl & Marjan paino $\mathrm{g}$ & Siemeniä kpl & Marjan paino $\mathrm{g}$ \\
Treatment & No. of seeds & Berry weight $\mathrm{g}$. & No. of seeds & Berry weight $\mathrm{g}$.
\end{tabular}

$\begin{array}{rrrrr}2 & 8.2 & 0.35 & 7.0 & 0.30 \\ 3 & 6.3 & 0.18 & 2.0 & 0.48 \\ 4 & 8.5 & 0.18 & - & -\end{array}$


Koska variseminen muissa maissa esitettyjen tietojen $(10,11,12)$ mukaan johtuu osaltaan marjoissa olevien siementen lukumäärän vähyydestä, määritettiin erikseen varisseiden marjojen siemenmäärät sekä marjanpainot (taulukko 10).

Verrattaessa taulukoiden 8 ja 9 siemenmääriä taulukossa 10 esitettyihin määriin sekä marjapainoihin havaitaan, että varisseissa marjoissa oli selvästi vähemmän siemeniä kuin kaikissa marjoissa keskimäärin. Varisseet marjat olivat myös keskimäärää keveämpiä. Näin variseminen ainakin suureksi osaksi nyt selostetuissa kokeissa johtui siemenmäärän vähyydestä, joka taas on seurausta pölytyksen vaillinaisuudesta.

\section{Tulosten tarkastelu}

Mustaherukan kukanaiheiden erilaistumista ei tähän mennessä ole selvitetty muutamaa lyhyttä mainintaa lukuun ottamatta, 60. leveysastetta pohjoisempana olevilta alueilta. Kuitenkin näillä seuduilla mustaherukka on helposti viljeltävä kasvi, jonka sadon laatu täällä saattaa olla poikkeuksellisen hyvä (4). Nyt selostetut tulokset valaisevat mustaherukan kehityksessä vaihetta, joka vaikuttaa ratkaisevasti tämän kasvin viljelyyn sekä sadon määrään. Havaitaan, että vielä pohjoisessa, lähellä napapiiriä, tapahtuu mustaherukan kukanaiheiden kehitystä talven aikana

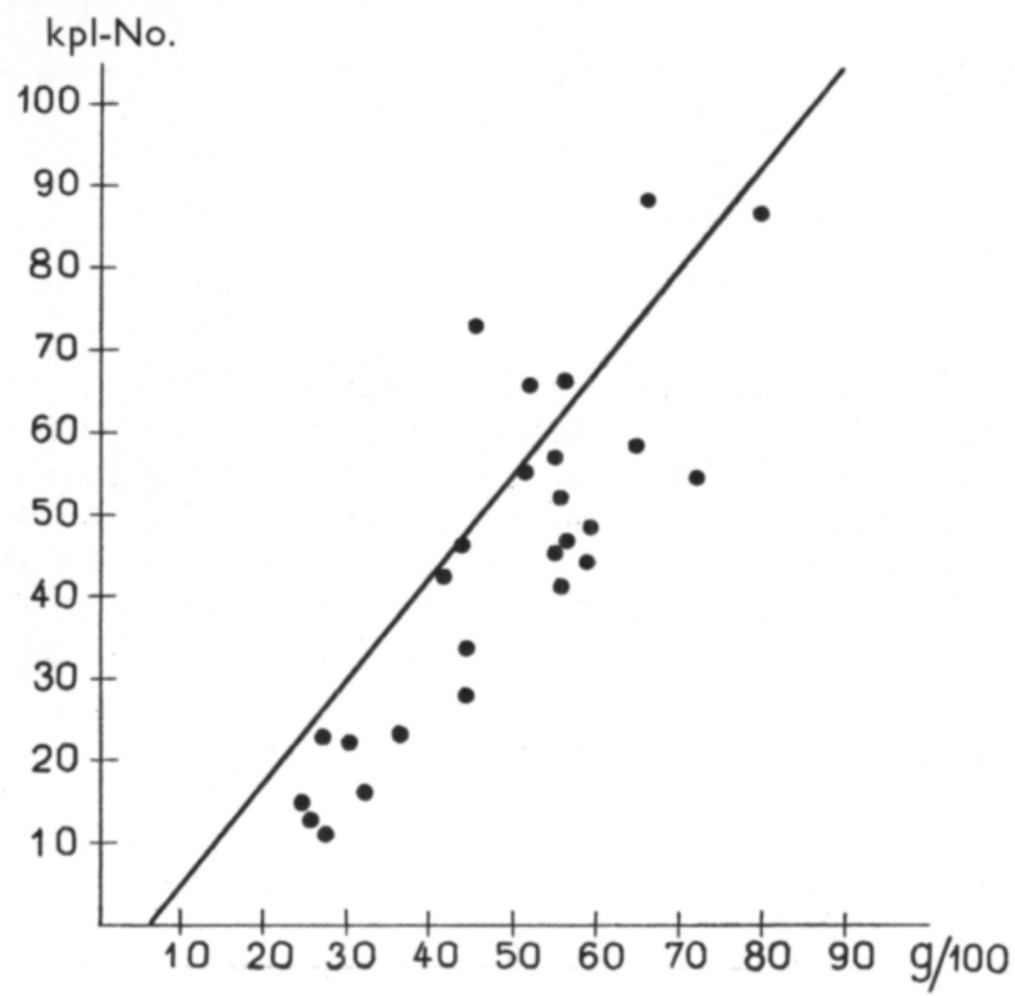

Kuva 2. Marjan painon ja siemenmäărän suhde. Korrelaatiokerroin +0.80 . Lajike Brödtorp v. 1963. Fig. 2. Relation of berry weight and number of seeds. Correlation coefficient +0.80. Variety Brödtorp in 1963. 


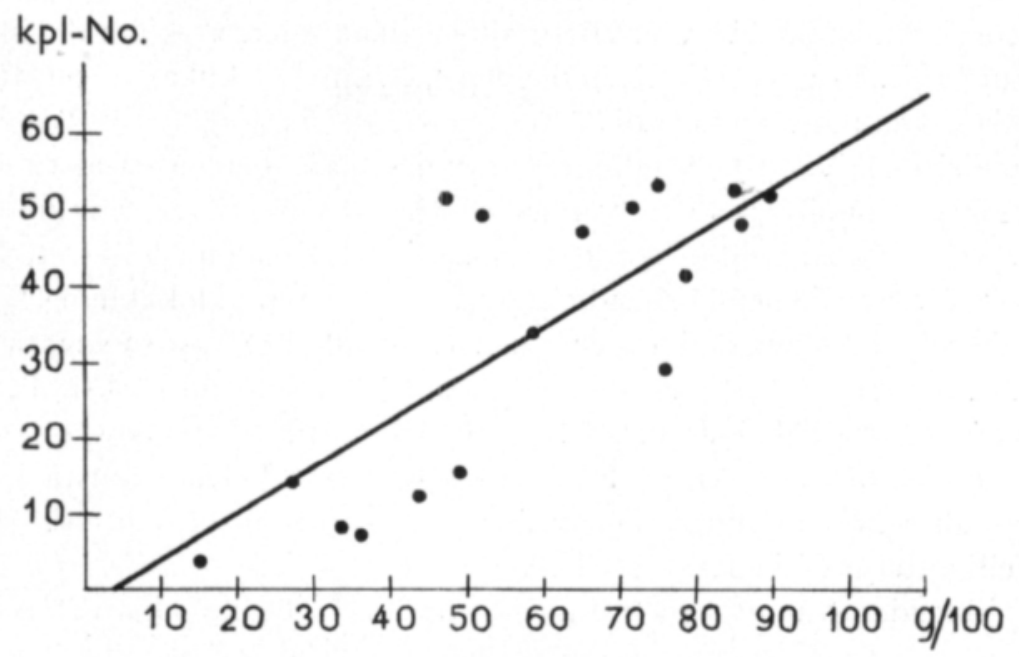

Kuva 3. Marjan painon ja siemenmäärän suhde. Korrelaatiokerroin +0.81. Lajike Lepaan musta v. 1963 .

Fig. 3. Relation of berry weight and number of seeds. Correlation coefficient +0.81. Variety Lepaan musta in 1963.

ja että sekä kotimaisten että kahden keskieurooppalaisen lajikkeen kukinta tapahtuu myös siellä normaalisti. Kukanaiheiden kehitysnopeus riippuu päivänpituudesta, ja kehitys näyttää alkavan vasta sitten, kun päivä on lyhentynyt noin 13 tuntiin.

Kotimaisista tutkituista lajikkeista Lepaan musta osoittautui täysin itsefertiilien ja Brödtorp osittain itsefertiilien ryhmään kuuluvaksi. Täten kumpaakin lajiketta voidaan viljellä yksinomaisena lajikkeena, mutta Brödtorpin satoisuus paranee, jos pölytys tapahtuu jonkin muun lajikkeen siitepölyllä. Pölyttäjälajikkeena oli Wellington xxx parempi kuin Lepaan musta. Vaillinaiseksi jäävä pölytys aiheuttaa raakileiden varisemista, koska niihin muodostuu tavallista vähemmän siemeniä, kuten myös muissa maissa on todettu. Lisäksi on marjan koko sitä pienempi, kuta vähemmän siinä on siemeniä (kuvat 2 ja 3). Erilaistumisen alkaessa on kasvin ravinteiden tarve suuri, mutta jos maan typpipitoisuus on tähän aikaan runsasta lisääntyy verson- ja lehdenkasvu ja aiheuttaa siten kukanaiheiden heikkenemistä sekä marjan varisemista seuraavana vuonna (9). Fosforilannoituksella voitaneen tällöin kukanaiheiden kehitystä edistää. Kummallekin kotimaiselle lajikkeelle antoi kukansisäinen pölytys sekä runsaammin että painavampia marjoja kuin saman lajikkeen muista kukista otetulla siitepölyllä suoritettu pölytys. On toistaiseksi epäselvää, mistä tämä johtui, mutta asian jatkuva selvittely tuonee lisävalaistusta kysymykseen.

\section{Ti ivistelmä}

Lepaan musta -lajikkeen kukanaiheiden erilaistuminen alkaa Viikissä heinäkuun 10. p:n, Rovaniemellä elokuun 10. p:n aikaan. Talvehtivan asteen kukanaiheet saavuttavat lokakuun loppuun mennessä. 
Brödtorpin kukanaiheiden erilaistuminen alkaa Viikissä kolmea viikkoa myöhemmin kuin Lepaan mustan kukanaiheiden, ja viimeiset kukanaiheet ovat talvehtimisasteella tammikuun puolivälissä.

Ulkomaisista lajikkeista Wellington xxx:n kukanaiheiden erilaistuminen alkoi Viikissä elokuun puolivälissä, Silvergieterin ja Laxtons Tinkerin kukanaiheiden elokuun 20. p:n aikaan, Oulun seudulla vastaavasti syyskuun 5. p:n aikaan ja lokakuun alussa, Rovaniemen korkeudella syyskuun 20. p:n ja lokakuun 1. p:n aikaan.

Mustaherukan kukanaiheiden erilaistuminen alkoi eri osissa maata vasta sen jälkeen kun luontainen päivä oli lyhennyt noin 13 tunnin pituiseksi. Tätä pitempi päivä viivyttää kukanaiheiden kehitystä, joten sanottu kehitys kasvissa on kvantitatiivisesti lyhyenpäivän reaktio. Kotimaiset lajikkeet Lepaan musta ja Brödtorp ovat tässä suhteessa paremmin sopeutuneet pitkänpäivän olosuhteisiin kuin ulkomaiset Wellington xxx ja Laxtons Tinker.

Eri lajikkeiden kukinta alkoi Viikissä vuonna 1962 2-4 päivää myöhemmin ja kesti 2-3 viikkoa kauemmin kuin v. 1963. Syynä näytti olevan alhaisempi toukokuun ja kesäkuun lämpötila v. 1962.

Lepaan musta kuuluu pölytyskokeiden perusteella täysin itsefertiileihin mustaherukkalajikkeisiin, Brödtorp osittain itsefertiileihin. Kumpaakin voidaan viljellä yksinomaisena lajikkeena, mutta Brödtorpin satoisuus on parempi, jos pölytys. tapahtuu vieraan lajikkeen siitepölyllä.

Kummallekin lajikkeelle aiheutti kukansisäinen pölytys paremman marjanmuodostuksen kuin lajikkeensisäinen kukkienvälinen pölytys.

\section{KIRJALLISUUS}

(1) Alleweldt, G. 1957. Der Einfluss von Photoperiode und Temperatur auf Wachstum und Entwicklung von Holzpflanzen unter besonderer Berücksichtigung der Gattung Vitis. Vitis 1: $159-180$.

(2) Bunning, E. \& Konder, M. 1954. Tageslänge, Blattwachstum und Blütenbildung. Planta 44: 9-17.

(3) Fernquist, I. 1961. Blombiologiska undersökningar hos svarta och röda vinbär samt krusbär. Kungl. Skogs- och Lantbr. Akad. Tidskr. 100: 357-397.

(4) HARDH, J. E. 1964. Mustaherukan C-vitamiinipitoisuuteen vaikuttavista tekijöistä. Maat.tiet. aikak. 36: 14-21.

(5) - - \& Vorpio, I. 1964. Photoperiodic responses in flower differentiation of blackcurrants. Proc. IVth Int. Photobiol. Congr., Oxford, p. 15.

(6) Кцӓмвт, H. D. 1958a. Untersuchungen über Entwicklung und Wuchsstoffhaushalt bei Ribes-Arten, I. Planta 50: 526-556.

(7) - 1958b. Untersuchungen über die Befruchtungsverhältnisse bei Schwarzen und Roten Johannisbeeren. Gartenbauwiss. 23:9-28.

(8) - - 1961. Die Befruchtungsverhältnisse bei Strauchbeerenobst. Der Erwerbsobstbau 3: 191 $-192$.

(9) LeNz, F. 1960. Untersuchungen zum Blühen und Fruchten einiger Kultursorten von Ribes rubrum L. und Ribes nigrum L. Dissertation. $116 \mathrm{~S}$. Stuttgart. 
(10) Neumann, U. 1953. Untersuchungen über die Ursachen des vorzeitigen Früchtefalls bei Schwarzen Johannisbeeren. Arch. f. Gartenbau 1: 63-111.

(11) - 1955a. Uber Beziehungen zwischen Wuchsstoffgehalt und Fruchtenwicklung bei Johannisbeeren. Ibid. 3: 274-296.

(12) - 1955b. Die Bedeutung der Befruchtungsverhältnisse und Pflegemassnahmen für den vorzeitigen Früchtefall bei Schwarzen Johannisbeeren. Ibid. 3: 339-354.

(13) Rudloff, C. F. \& Lenz, F. 1960. Zur Wertigkeit der Johannisbeerblüten. Der Erwerbsobstbau 2: $214-217$.

(14) - - \& LENz, F. 1961. Die Blütendifferenzierung an Johannisbeeren. Ibid. 3: 36-38,

(15) Tenotia, S. S. \& Luckwill, L. C. 1955. Fruit drop in black currants, I. Factors affecting orunning off. Ann. Rep. Res. Sta. Long Ashton 1955: 64-74.

(16) Tyrina, V. A. 1958. O zimnem rasvitii potšek (silmujen kasvu talven aikana). Fisiologia Rastenii 5: $177-179$.

(17) VıткоvsкıJ, V. L. 1962. Potškovyie novoobrasovanie y tšernoi smorodiny (mustaherukan silmujen kehitys). Bot. Žurn. 47: 394-398.

(18) Wright, S. T. C. 1956. Studies of fruit development in relation to plant hormones, III. Auxins in relation to fruit morphogenesis and fruit drop in the black currant Ribes nigrum. J. Hort. Sci. 31: $196-211$.

(19) Zeller, O. 1955. Entwicklungsverlauf der Infloreszenzknospen einiger Kern- und Steinobstsorten. Angew. Bot. 29: 69-89.

(20) - 1964a. Entwicklungsrhythmen von Obstgewächsen in Finnland, I. Maat.tiet. aikak. 36: $85-105$.

(21) - - 1964b. Entwicklungsmorphologische Studien an Blütenknospen von Rubus arcticus L. und Rubus chamaemorus L. in Finnland. Beiträge zur Phytologie, Sonderdr.: 1-18.

\section{S U M M A R Y:}

\section{FLOWER FORMATION AND BERRY GROWTH IN BLACK CURRANT}

\section{J. E. HÁrdh \& Johanna Wallden}

Department of Horticulture, University of Helsinki, Viik, Pihlajamäki.

Development of flower primordia in the areas north of the 60th latitude is scarcely known. The differentiation data on Lepaan musta (Lepaa black), Brödtorp, Wellington xxx and of Silvergieter (Silvergieters Zwarte) in Viik, close to Helsinki, are given (Tables 2 and 3). Table 4 gives the differentiation stages of Lepaan musta, Brödtorp, Wellington xxx and of Laxtons Tinker on four latitudes in Finland. It is clear that differentiation is delayed by the long day in the north (Table 5) and that a daylength of less than 13 hours favours the differentiation process. This was confirmed in tests with an artificial prolonging of the day (Table 6). The Finnish varieties Lepaan musta and Brödtorp seem to be more adapted to the long day conditions than Wellington $x x x$ and Laxtons Tinker.

Development of the primordia occurs during winter, despite the temperature remaining far below zero, until the fifth stage $(9,20)$, where overwintering occurs (Table 3). Flowering data are given in Table 7 .

In pollination tests in 1963 and 1964 it was shown that Lepaan musta belongs to the completely self-fertile varieties, Brödtorp to partially self-fertile ones (7, 8, 12). On Lepaan musta and Brödtorp the intrafloral self-pollination gave better berry formation than interfloral self-pollination. Of the pollinating varieties Wellington $\mathbf{x x x}$ was more vigorous than the domestic varieties Lepaan musta for Brödtorp and vice versa (Tables 8 and 9)., Running off in the tests was stated to depend on a low number of seeds in the berries (Table 10). Close correlation existed between the size of berry and the number of seeds (Figures 2 and 3). 